\title{
Cultivation of Button Mushroom (Agaricus bisporus) Under Controlled Condition: An Initiative in Bastar Plateau of Chhattisgarh
}

\author{
R.S. Netam ${ }^{1}$, S.C. Yadav², S.C. Mukherjee ${ }^{1}$ and Poonam Kumari ${ }^{\text {* }}$ \\ ${ }^{1} S$ G College of Agriculture and Research Station, Jagdalpur-494005, Indira Gandhi \\ Agricultural University, Raipur, Chhattisgarh, India \\ ${ }^{2}$ Krishi Vigyan Kendra, Alwar, Rajasthan, India \\ *Corresponding author
}

\section{A B S T R A C T}

\begin{tabular}{|l|}
\hline Key w or d s \\
Spawn, Pinning, \\
Casing, Composting
\end{tabular}

The experiment was conducted at Mushroom Production unit at SG College of agriculture and research station, Jagdalpur during July 2017-January 2018 under controlled condition. Fresh culture of Agaricus bisporus S-11 was maintained on potato dextrose agar. Compost was prepared by short method of composting and cultivation trials of Agaricus bisporus S11 was carried out in a closed room provided with air conditioner as source of cooling. The relative humidity inside the cropping rooms was maintained to $60-70 \%$. Spawn run completed in 15 days and required 12-15 days more for case run. The pinheads developed into solid button sized mushrooms in another 5-7 days. Morphological characteristics recorded for this mushroom revealed an average stipe length of $3.02 \mathrm{~cm}$ having girth of 1.7 $\mathrm{cm}$. While the average pileus length and width was $2.1 \mathrm{~cm}$ and $3.37 \mathrm{~cm}$ respectively. Mushroom yield of $18.17 \mathrm{~kg} / 100 \mathrm{Kg}$ compost was recorded. Average weight of mushroom recorded was $19.1 \mathrm{~kg}$ with average number of fruiting bodies of 960 from $100 \mathrm{~kg}$ of compost. Benefit cost ratio for mushroom cultivation was estimated to be 1.98 .

\section{Introduction}

Agriculture has remain be the major force of Indian economy but a fight is still on to meet the ever increasing demand of nutritional security following secondary agricultural vocation. To meet such challenges, diversification in the agricultural activities which include mushroom production is important to address the problems of quality food, health and environmental sustainability (Singh et al., 2017). In the present diet conscious era, mushrooms are increasingly considered as a future vegetable and their consumer demand has markedly expanded in the recent years owing to its medicinal and nutritional properties. Mushrooms are considered as a potential substitute of muscle protein on account of their high digestibility (Pavel, 2009). In addition to protein, mushroom is an excellent source of vitamin$\mathrm{D}$, minerals such as potassium, iron, copper, zinc and manganese, low in calories, fat free, cholesterol free, gluten free and very low in sodium (Sharma et al., 2017). From 20102017, the mushroom industry in India has registered an average growth rate of $4.3 \%$ per annum. Out of the total mushroom produced, 
white button mushroom share is $73 \%$ followed by oyster mushroom (16\%), paddy straw mushroom (7\%) and milky mushroom (3\%) (Sharma et al., 2017).

The white button mushroom (Agaricus bisporus) is very popular throughout the world and is the most important mushroom of commercial significance in India (Maheswari 2013). It belongs to phylum Basidiomycota, class Agaricomycetes, order Agaricales and family Agaricaceae. Initially, white button mushroom production was confined to temperate hilly regions of India. However, with the development of short method of composting and optimization of fruiting conditions using the chilling system, there has been a remarkable change in its production scenario and spread to all the corners of the country. Considering this, experiment was designed to cultivate button mushroom under laboratory condition as climate of Bastar plateau of Chhattisgarh does not permit for natural button mushroom production.

\section{Materials and Methods}

\section{Organism and culture conditions}

Fresh pure culture of Agaricus bisporus S-11 was procured from Indira Gandhi Agricultural University (IGKV), Raipur. The culture was grown on Potato Dextrose Agar (PDA) medium. The culture was stored at $4{ }^{\circ} \mathrm{C}$ and sub cultured periodically at an interval of three weeks.

\section{Spawn production}

Wheat grains were used as support media for spawn production. Wheat grains were boiled in water for $30 \mathrm{~min}$ (wheat grains: water, 1:2 w/v) so as to cook them soft enough to be pressed within the fingers. Extra water was sieved out, the grains were allowed to cool and then mixed with calcium carbonate and calcium sulphate powder@10g/kg of wheat grains respectively. Empty glucose bottles were filled with these grains @ $250 \mathrm{~g}$ per bottle, plugged with non-absorbent cotton, wrapped with paper and then autoclaved at 15 psi for $30 \mathrm{~min}$. After cooling the autoclaved bottles overnight, these were shaken to restore transparent visibility of the glass and then inoculated aseptically with mycelial bits from the slant cultures. The bits were placed in such a manner that their mycelium touched the grains. These bottles were incubated at $22 \pm 1^{\circ} \mathrm{C}$ for $15-20$ days. The culture bottles thus produced were the Master/mother cultures. After 10 days, Master/mother culture was shaken so that grains were transferred into 10-15 freshly prepared bottles. These spawn bottles were stored at $25^{\circ} \mathrm{C}$ to use for spawning the substrate.

\section{White button mushroom cultivation method}

\section{Composting}

Fresh, good quality wheat straw was spread on pucca floor and wetted thoroughly for 48 hours while keeping it in the form of loose heap $(=0.5 \mathrm{~m}$ high) to attain $70-75 \%$ moisture content. Considering stacking day as 0 day, first turning was done 3 days after stacking, urea @ $1.8 \mathrm{~kg} /$ qt of straw was mixed with wet straw, again stacked into heap and covered with polythene and kept overnight to facilitate solubilization of the chemical fertilizer and their adsorption on to the bran.

Subsequent turning was done at 3 days interval with a total of seven turns required for complete decomposition of compost. Wheat bran (choker) @ $2.5 \mathrm{~kg}$ per quintal of straw was mixed during $3^{\text {rd }}$ turning, while gypsum was mixed during $6^{\text {th }}$ turning @ $3.5 \mathrm{~kg} / \mathrm{qt}$ of straw. Light brown colored compost having no smell of ammonia was allowed to cool down before spawning (Garcha and Kiran, 1981). 


\section{Filling and spawning}

Good quality compost was mixed with $A$. bisporus spawn (@ 0.7-1.0\% of wet compost weight) and filled into polythene bags of size $18 \times 20^{\prime \prime}$. The spawned compost was then compressed, leveled and mouth of polythene bags was covered with a clean newspaper. Compost filled bags were then shifted to the growing room until complete mycelia impregnation. Holes were made throughout the bag to allow aeration. The filled bags were incubated at $21 \mathrm{C}-23{ }^{\circ} \mathrm{C}$ with sufficient light and humidity and water was sprayed on top of the bags covered with newspaper, twice a day throughout spawn running period.

\section{Casing}

Casing mixture was prepared by mixing cocopeat, soil and sand (3:2:1 v/v). Coco-peat instead of farmyard manure was used because of easy availability in Bastar plateau. Moreover, because of its unique water holding and structural properties, coco-peat has been regarded as the most suitable and more ideal for casing (Kaur and Rampal, 2017). All the ingredients were separately sterilized for 30 minute at $121^{\circ} \mathrm{C}$ at $15 \mathrm{psi}$ before mixing. The sterilized casing mixture was used to cover spawn impregnated compost bags at uniform thickness of 3-4 cm following removal of newspaper. Case run was considered complete when mycelia covered the top of casing layer. Case run was done at a temperature of $21-23$ ${ }^{\circ} \mathrm{C}$. Spraying of water was continued directly on cased bags till the end of cropping.

\section{Crop management and harvesting}

An air conditioner room of $10 \times 12$ sq. feet was used for cultivation. Very little or no ventilation was provided until the appearance of first pin heads. Thereafter intermittent cross- ventilation was given for period of total 3-4 hrs per day. A temperature of $21-23^{\circ} \mathrm{C}$ was maintained during spawn run period and $15-20^{\circ} \mathrm{C}$ after pin head stage. Relative humidity of 70-80 percent was maintained throughout the cultivation. Mushrooms were harvested by gentle twisting and the soil end parts of fruit bodies were cut off. The yield data was recorded daily for number of fruit bodies and their weight was observed. Spray of water was also continued on cased bags till end of crop. Yield data for total number and total weight of fruiting bodies per bag was recorded up to a period of 4 weeks following appearance of pin head and biological efficiency was calculated as

Total weight of fresh mushroom Biological efficiency = ----------------- X 100

Total dry weight of compost

\section{Estimation of gross income, net profit and benefit cost ratio}

Gross income was calculated by multiplying the total production of mushroom by the selling price (Rs 200/Kg of mushroom). Net profit was calculated by subtracting total production cost from gross income. Benefit cost ratio was calculated by dividing total income by total expenditure.

\section{Results and Discussion}

The experiment was conducted at Mushroom Production unit at SG College of agriculture and research station, Jagdalpur during July 2017-January 2018 under laboratory condition. Fresh culture of Agaricus bisporus $\mathrm{S}-11$ was maintained on potato dextrose agar.

The fungal strain exhibited full mycelial growth $(9 \mathrm{~cm})$ in $22-25$ days at $22^{\circ} \mathrm{C}$. In their study Yadav and Chandra (2014) reported that mycelial growth of three strains of Agaricus bisporus S-79, A-15 and Delta on PDA were obtained fast and full growth $(9 \mathrm{~cm})$ completed in 8, 10 and 12 days respectively. 
The data for cultivation of button mushroom has been depicted in table 1 which comprised growth behavior, morphological characteristics and yield attributes. The results indicated that the spawn run completed in 15 days and required 12-15 days more for case run. During this period no ventilation was provided as there is no requirement for fresh air introduction during case run. After case run, the environmental conditions was changed by bringing down the temperature to $16-18^{\circ} \mathrm{C}$ provided by air conditioner and providing proper ventilation for exhausting excess $\mathrm{CO}_{2}$. This change in environmental parameters induced pinhead formation in 2-3 days time. The pinheads developed into solid button sized mushrooms in another 5-7 days.

At this stage, the air inside the cropping room was changed 4-6 times to maintain appropriate $\mathrm{CO}_{2}$ concentration as $\mathrm{CO}_{2}$ production is at its peak during first flush. The subsequent harvesting was made at an interval of 4-5 days and data was recorded for 4 weeks. In a report evaluating different strains of Agaricus bisporus, Kumar et al., (2017) reported that number of days taken for spawn run ranged from 14-17, minimum being in NCS-465 (14 days) and maximum in NCS-459 and A-15 (17days), while time required for case run ranged for 13-18 days and pinhead formation from 15-21 days.

Morphological characteristics recorded for this mushroom revealed an average stipe length of $3.02 \mathrm{~cm}$ having girth of $1.7 \mathrm{~cm}$. While the average pileus length and width was $2.1 \mathrm{~cm}$ and $3.37 \mathrm{~cm}$ respectively. Kumar et al., (2017) reported average length of stalk in the range of 1.6-3.5 cm, maximum was observed in Portbella $(3.5 \mathrm{~cm})$ followed by A-15 $(3.2 \mathrm{~cm})$, U-3 $(2.8 \mathrm{~cm})$, Delta $(2.4 \mathrm{~cm})$, NCS-459 (2.2 $\mathrm{cm}$ ), and minimum average length of stalk was NCS-465 $(1.6 \mathrm{~cm})$, whereas width of stalk ranged from 1.2-2.5, maximum again being with Portbella $(2.5 \mathrm{~cm})$. They further reported average length of mushroom cap in range of $3.0-5.0$ and width $3.0-4.8 \mathrm{~cm}$.

Table.1 Cultivation of Agaricus bisporus under laboratory condition

\begin{tabular}{|l|l|}
\hline Growth behavior & 15 \\
\hline Spawn run (d) & $12-15$ \\
\hline Case run (d) & $2-3$ \\
\hline Pin head emergence (d) & $5-7$ \\
\hline First harvest (d) & 30 \\
\hline Last harvest (d) & \\
\hline Yield performance & 18.17 \\
\hline Yield (kg/100kg) & 979 \\
\hline Number of fruit bodies (/100kg) & 19.1 \\
\hline A verage weight of fruit bodies (g) & 18.17 \\
\hline Biological efficiency (\%) & \\
\hline Morphological characteristics & 3.02 \\
\hline Average stipe length (cm) & 1.7 \\
\hline Average stipe girth (cm) & 2.1 \\
\hline Average pileus length (cm) & 3.37 \\
\hline Average pileus width (cm)
\end{tabular}


Table.2 Economics of mushroom cultivation under laboratory condition (Production cost per $500 \mathrm{Kg}$ of compost)

\begin{tabular}{|l|l|}
\hline Expenditure & Rupees \\
\hline Wheat straw @ Rs 1200/100kg & 6000 \\
\hline Labour & 4500 \\
\hline Electricity charges & 1500 \\
\hline Spawn, polythene bags & 1500 \\
\hline Miscellaneous (Urea, gypsum, wheat bran etc.) & 500 \\
\hline Total expenditure & $\mathbf{1 2 5 0 0}$ \\
\hline Income (124.42 Kg mushroom @ Rs 200/kg) & $\mathbf{2 4 8 0 4}$ \\
\hline Net income & $\mathbf{1 2 3 8 4}$ \\
\hline Benefit cost ratio & $\mathbf{1 . 9 8}$ \\
\hline
\end{tabular}

Enlightening the yield performance, mushroom yield of $18.17 \mathrm{Kg} / 100 \mathrm{Kg}$ compost was recorded. Average weight of mushroom recorded was $19.1 \mathrm{~kg}$ with average number of fruiting bodies of 979 from $100 \mathrm{~kg}$ of compost. Diamatopoulou and Philippoussis (2001) observed maximum yield $(30.84 \mathrm{~kg}$ of edible mushroom biomass) in white strain 207 among five Agaricus bisporus strains. Singh et al., (2017) recorded $18.27 \mathrm{~kg} / 100 \mathrm{~kg}$ compost yield from AVT-02 followed by $14.30 \mathrm{Kg} / 100 \mathrm{~kg}$ compost from AVT-06 button mushroom strains. Kumar et al., (2017) reported average individual fruit body weight of $12.00 \mathrm{gm}$ while Singh et al., (2017) recorded maximum average weight of fruit body of 14.79 in AVT-01.

Environment controlled mushroom production unit of size $10 \times 12$ sq. feet was used in the present experiment. Table 2 presenting the economics of mushroom cultivation (per $500 \mathrm{Kg}$ of compost) under controlled condition revealed a total income of Rs 24,804 against total expenditure of Rs 12,500 with benefit cost ratio of 1.98 . Use of family labour for different operations may further reduce the expenditure making the farmer self-confident in raising the crop with great remuneration. While investigating economics of button mushroom production in selected areas of Bangladesh, Barmon et al.,
(2012) found mushroom to be a profitable agricultural enterprise with a benefit cost ratio (BCR) of 1.55 .

The present results indicate that button mushroom can possibly be cultivated under laboratory condition. This can be a means of livelihood and a source of economic empowerment for women in both urban and rural areas, and for small holder farmers, apart from being a source of food production.

\section{References}

Barmon, B. K., Sharmin, I., Abbasi, P. K. and Mamun A. 2012. Economics of Mushroom (Agaricus bisporus) production in a selected upazila of Bangladesh. The Agriculturists. 10, 7789.

Diamantopoulou, P., and Philippoussis, A. 2001. Production attributes of Agaricus bisporus white and off-white strains and the effect of calcium chloride irrigation on productivity and quality. Sci. Horti. 91, 379-391.

Garcha, H. S., and Kiran, U. 1981. Studies on mushroom composts under tropical conditions. Mush. Sci. 11, 219-233.

Kaur, A. P., and Rampal, V. K. 2017. Assessment of Casing Mixtures on Yield Potential and Quality of Button 
Mushroom (Agaricus bisporus) - On Farm Trial. Int. J. Current. Microbiol. Appl. Sci. 6(2), 430-436.

Kaur, S., S. Kapoor, and Sodhi, H. S. 2014 Screening and Evaluation of Agaricus bisporus (Lange) Sing. Strains for temperature variability. Int. J. Current. Microbiol. Appl. Sci. 3(6), 120-127.

Kumar, S., Doshi, A., Kumar, D., and Singh, K. 2017. Evaluation of High Yielding Strains of Agaricus bisporus (Lange) Sing. Int. J. Current. Microbiol. Appl. Sci. 6(5), 1697-1702.

Maheshwari, S. 2013. A guide for white button mushroom (Agaricus bisporus) production. Scientific. Reports. 2:668. doi:10.4172/scientificreports.668.
Pavel, K. 2009. Chemical composition and nutritional value of European species of wild growing mushrooms: A review. Food. Chem. 113(1), 9-16.

Sharma, V. P., Annepu, S. K., Gautam, Y., Singh, M., and Kamal, S. 2017. Status of mushroom production in India. Mushr. Res. 26 (2), 111-120.

Singh, M. P., Kaur, S., and Sodhi, H. S. 2017. Evaluation of Agaricus bisporus Lange (Sing.) Strains in the Plains of Punjab, India. Int. J. Current. Microbiol. Appl. Sci. 6(12): 3417-3425

Yadav, M. K., and Chandra, R. 2014. Effect of culture media, $\mathrm{pH}$ and temperature on mycelial growth of Agaricus Bisporus strains. J. Pure. Appl. Microbiol. 8(3), 1-6.

\section{How to cite this article:}

Netam, R.S., S.C. Yadav, S.C. Mukherjee and Poonam Kumari. 2018. Cultivation of Button Mushroom (Agaricus bisporus) Under Controlled Condition: An Initiative in Bastar Plateau of Chhattisgarh. Int.J.Curr.Microbiol.App.Sci. 7(10): 782-787. doi: https://doi.org/10.20546/ijcmas.2018.710.087 